\title{
PRAT tool: a harmonization of antimicrobial stewardship program interventions
}

\author{
Marinei Campos Ricieri ${ }^{* *}$ (D), Heloísa Arruda Gomm Barreto ${ }^{10}$, Harli Pasquini-Netto² (1),

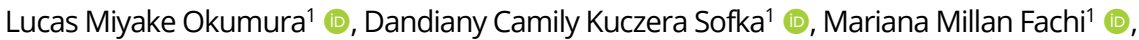 \\ Fábio Araújo Motta ${ }^{1 *}$ (1) \\ ${ }^{1}$ Hospital Pequeno Príncipe, Curitiba, PR, Brasil \\ ¿Unimed, Curitiba, PR, Brasil \\ *Corresponding author: marinei.ricieri@hpp.org.br
}

\begin{abstract}
Objective: The Antimicrobial Stewardship Program (ASP) in hospitals aims to promote the rational use of antimicrobials, providing better results to patients (increasing effectiveness and decreasing the risk of adverse events), hospital epidemiology (impact on levels of microbial resistance), and enable cost-effectiveness studies. Therefore, a tool (called PRAT- antimicrobial therapy-related problem) is suggested in this paper. This unvalidated tool is the initial step towards organizing the antimicrobial therapy-related interventions to improve the use of this drug class, mainly by suggesting a harmonized registry process of ASP interventions. Methods: Therefore, this work presents the PRAT tool, developed based on the 10 years' experience of ASP at Pequeno Príncipe Hospital, inspired by the classification for drug-related problems of the Pharmaceutical Care Network Europe and according to a collaborative work using the Delphi technique. Results: This tool allows the identification and exact description of the antimicrobial therapy-related problem in 17 domains and 67 subcategories. Based on this identification, it suggests how to classify this problem (effectiveness, safety and need/indication) and what interventions can be conducted. Conclusion: This tool has the potential to establish a profile of antimicrobial-related problems, allowing prioritization to be visualized through the most (and least) interventions made in a given period, and might be useful in improving the quality of care through settings, by means of targeted educational interventions. Furthermore, if there is a harmonization of terminology for the classification of antimicrobial therapy-related problems, other hospitals can adopt it, and so the tool can improve research and comparison between institutions (benchmarking).
\end{abstract}

Keywords: Anti-infective agents; Hospitals; Drug therapy.

\section{How to cite}

Ricieri M, Barreto H, Pasquini-Netto H, Okumura L, Sofka D, Fachi M, Motta F. PRAT tool: a harmonization of antimicrobial stewardship program interventions. Rev Ciênc Farm Básica Apl. 2021;42:e735. https://doi.org/10.4322/2179-443X.0735

The concept of the Antimicrobial Stewardship Program (ASP) was first introduced by John E. McGowan Jr and Dale N. Gerding in the USA, and was then included in 1997 in the guidelines of the Society for Healthcare Epidemiology of America (SHEA) and the Infectious Diseases Society of America (IDSA) for the prevention of antimicrobial resistance in hospitals. ASP refers to a program or series of coordinated interventions 
designed to improve and measure the appropriate use of antimicrobial agents in a health institution, promoting cost savings, optimizing therapeutic results and reducing antimicrobial resistance ${ }^{1-3}$.

However, an additional step is required for ASP: without one harmonized classification system of antimicrobial-related problems, it will be difficult to measure the attributable clinical and economic benefits of such programs. This classification has the potential to define a profile of the real antimicrobial therapy-related problem of health institutions.

Harmonization implies making different people, plans and situations suitable for each other, so they can work together more easily ${ }^{4}$. From this semantic standpoint, harmonization was one of the main legacies of the Centers for Disease Control (CDC) and Clinical and Laboratory Standards Institute (CLSI)5. In 1977, CDC, CLSI and other entities defined the Certified Reference Materials (CRMs) and Reference Measurement Procedures (RMPs) for laboratorial investigations of infectious diseases. Without CRMs and RMPs, there would not be standards for appropriate diagnosis and treatment of infectious diseases, which is the foundation for the ASP: "correct drug for the correct bug"6,7.

All countries have generally come to the consensus that ASP can promote the better use of antimicrobial agents ${ }^{8,9}$. Van Dijck et al. ${ }^{9}$ suggested that accurate descriptions of interventions, implementation strategies and inclusion of behavioral aspects should be priorities to improve the scientific evidence in antimicrobial program.

Furthermore, structured and standardized classification systems that are considered comprehensive and easy to apply to pharmacotherapeutic problems, with little time spent in daily clinical practice are rare ${ }^{10}$.

It is necessary that this classification is comprehensive and easy to apply, given the reduced time that professionals have for registration activity, and, preferably, does not compromise the daily clinical practice ${ }^{10}$.

A standardized classification with high acceptance among ASP professionals and researchers would increase knowledge about the process and the results ${ }^{8}$. To our knowledge, there are no specific classifications for problems and interventions with antimicrobials, therefore, our objective is to present a tool that classifies these problems, which was developed based on the long experience of the ASP of Pequeno Príncipe Hospital (HPP) and which has the potential to be used by other institutions that adopt an antimicrobial management program.

Accumulating experience in the observation and detailed description of a series of antimicrobial therapy-related problems, associated with the consolidation of the ASP, and creation of a field of action (Antimicrobial Stewardship) of the Multiprofessional Residence in Child and Adolescent Health, the ASP-HPP team improved the harmaceutical Care Network Europe $(\mathrm{PCNE})^{10}$ classification locally by describing subcategories with specific problems with antimicrobials, detected daily and over more than 10 years of service experience.

A collaborative work with key staff from the hospital allowed a stepwise development of the tool and is described as below using a pragmatic approach:

1) An initial evaluation of the most common interventions and antimicrobial-related problems found in ASP practice.

2) More than 5 years of discussions to define and set the tool, involving five pharmacists, an infectious disease physician and an Infection Control Team.

3) Validation of the tool is ongoing, and a large database with more than 10,000 interventions is being cleaned and will be soon analyzed.

The PRAT (antimicrobial-related problem) tool is presented in Table 1. This tool has two drivers: a) identification of the general problem domain and its specific problem related to the use of an antimicrobial; b) and their respective conduct (intervention) to improve drug therapy for infections. 
Table 1. Systematization of codes for pharmacotherapeutic interventions associated with antimicrobials

\begin{tabular}{|c|c|c|c|c|c|}
\hline Code & $\begin{array}{c}\text { Primary domain of the } \\
\text { problem identified }\end{array}$ & Subcode & PRAT Description & $\begin{array}{c}\text { Suggested } \\
\text { intervention }\end{array}$ & $\begin{array}{c}\text { Classification of the } \\
\text { problem }\end{array}$ \\
\hline \multirow{6}{*}{1} & \multirow{6}{*}{ Prescribed dose } & 1.1 & $\begin{array}{l}\text { Subdose based on literature } \\
\text { and/or protocol }\end{array}$ & To increase dose & $E$ \\
\hline & & 1.2 & $\begin{array}{c}\text { Subdose according to the ATM } \\
\text { serum level }\end{array}$ & To increase dose & $E$ \\
\hline & & 1.3 & $\begin{array}{l}\text { Subdose based on creatinine } \\
\text { clearance or edema/obesity }\end{array}$ & To increase dose & $E$ \\
\hline & & 1.4 & $\begin{array}{l}\text { Overdose based on literature and/or } \\
\text { protocol }\end{array}$ & To decrease dose & $\mathrm{S}$ \\
\hline & & 1.5 & $\begin{array}{l}\text { Overdose according to the ATM } \\
\text { serum level }\end{array}$ & To decrease dose & $\mathrm{S}$ \\
\hline & & 1.6 & $\begin{array}{l}\text { Overdose based on creatinine } \\
\text { clearance or edema/obesity }\end{array}$ & To decrease dose & $\mathrm{S}$ \\
\hline \multirow{2}{*}{2} & \multirow{2}{*}{ Frequency } & 2.1 & $\begin{array}{l}\text { Increased frequency (shortest } \\
\text { interval) }\end{array}$ & $\begin{array}{c}\text { To decrease } \\
\text { frequency (to } \\
\text { increase the interval) }\end{array}$ & $\mathrm{S}$ \\
\hline & & 2.2 & $\begin{array}{l}\text { Decreased frequency (longest } \\
\text { interval) }\end{array}$ & $\begin{array}{l}\text { To increase frequency } \\
\text { (to decrease the } \\
\text { interval) }\end{array}$ & E \\
\hline \multirow{3}{*}{3} & \multirow{4}{*}{ Route of administration } & 3.1 & $\begin{array}{l}\text { Not appropriate route of } \\
\text { administration for the clinical } \\
\text { condition }\end{array}$ & To replace route & E or $S$ \\
\hline & & 3.2 & $\begin{array}{l}\text { Loss of venous access or patient } \\
\text { with criteria to start antibiotic } \\
\text { switch therapy }\end{array}$ & $\begin{array}{l}\text { To perform switch } \\
\text { therapy (from IV to } \\
\text { Oral) }\end{array}$ & E or $S$ \\
\hline & & 3.3 & $\begin{array}{c}\text { Loss of venous access or patient } \\
\text { with criteria to start antifungal } \\
\text { switch therapy }\end{array}$ & $\begin{array}{l}\text { To perform switch } \\
\text { therapy (from IV to } \\
\text { Oral) }\end{array}$ & E or $S$ \\
\hline \multirow[b]{2}{*}{4} & & 4.1 & $\begin{array}{l}\text { Not appropriate dosage form for } \\
\text { the route of administration }\end{array}$ & $\begin{array}{l}\text { To replace dosage } \\
\text { form }\end{array}$ & E or $S$ \\
\hline & \multirow[t]{3}{*}{ Dose form } & 4.2 & $\begin{array}{l}\text { Intolerance due to medication } \\
\text { palatability }\end{array}$ & $\begin{array}{l}\text { To change dosage } \\
\text { form/to administer } \\
\text { with food/ other }\end{array}$ & E or $S$ \\
\hline \multirow{4}{*}{5} & & 5.1 & $\begin{array}{l}\text { Patient without infection and } \\
\text { using ATM (empirical initial use) }\end{array}$ & & $N / l$ \\
\hline & & 5.2 & Extended time of antibiotic therapy & & $N / I$ \\
\hline & \multirow[t]{2}{*}{ Unnecessary medication } & 5.3 & Extended antibiotic prophylaxis & To suspend ATM & $N / l$ \\
\hline & & 5.4 & $\begin{array}{c}\text { Patient with unnecessary ATM } \\
\text { association based on culture or clinic } \\
\text { results }\end{array}$ & & $N / I$ \\
\hline \multirow{11}{*}{6} & \multirow{11}{*}{$\begin{array}{l}\text { Inadequate } \\
\text { pharmacotherapy }\end{array}$} & 6.1 & $\begin{array}{l}\text { Microorganism resistant to the } \\
\text { ATM according to antibiogram }\end{array}$ & To replace ATM & $\mathrm{E}$ \\
\hline & & 6.2 & $\begin{array}{l}\text { Empirical therapy not consistent with } \\
\text { epidemiology or laboratory/images } \\
\text { results }\end{array}$ & To replace ATM & E or N/I \\
\hline & & 6.3 & $\begin{array}{c}\text { Patient with previous allergy to } \\
\text { the ATM }\end{array}$ & To replace ATM & $S$ \\
\hline & & 6.4 & $\begin{array}{c}\text { ATM off label use with adverse } \\
\text { event/adverse reaction } \\
\text { occurrence }\end{array}$ & To replace ATM & S \\
\hline & & 6.5 & $\begin{array}{l}\text { Subtherapeutic serum dosage } \\
\text { maintained after ATM dose } \\
\text { adjustment }\end{array}$ & To replace ATM & E \\
\hline & & 6.6 & $\begin{array}{l}\text { Microorganism unresponsive to ATM } \\
\text { or patient with no clinical response }\end{array}$ & $\begin{array}{l}\text { To increase dose or } \\
\text { replace ATM }\end{array}$ & E \\
\hline & & 6.7 & $\begin{array}{l}\text { ATM without tissue penetration } \\
\text { into the infectious site }\end{array}$ & $\begin{array}{l}\text { To increase dose or } \\
\text { replace ATM }\end{array}$ & E \\
\hline & & 6.8 & $\begin{array}{l}\text { ATM with narrow-spectrum } \\
\text { activity for the patient's clinical } \\
\text { condition or culture result }\end{array}$ & $\begin{array}{l}\text { To perform ATM } \\
\text { escalation }\end{array}$ & $N / I$ \\
\hline & & 6.9 & $\begin{array}{l}\text { ATM with broad-spectrum activity } \\
\text { for the patient's clinical condition } \\
\text { or culture result }\end{array}$ & $\begin{array}{l}\text { To perform ATM de- } \\
\text { escalation }\end{array}$ & $N / I$ \\
\hline & & 6.10 & $\begin{array}{l}\text { Worsening of kidney or liver } \\
\text { function using ATM }\end{array}$ & To replace ATM & $S$ \\
\hline & & 6.11 & $\begin{array}{l}\text { Therapy not consistent with the } \\
\text { institutional protocol }\end{array}$ & To replace ATM & $N / I$ \\
\hline
\end{tabular}


Table 1. Continued...

\begin{tabular}{|c|c|c|c|c|c|}
\hline Code & $\begin{array}{c}\text { Primary domain of the } \\
\text { problem identified }\end{array}$ & Subcode & PRAT Description & $\begin{array}{c}\text { Suggested } \\
\text { intervention }\end{array}$ & $\begin{array}{c}\text { Classification of the } \\
\text { problem }\end{array}$ \\
\hline \multirow{7}{*}{7} & \multirow{7}{*}{$\begin{array}{c}\text { Insufficient } \\
\text { pharmacotherapy }\end{array}$} & 7.1 & $\begin{array}{c}\text { Patient with previous allergy to } \\
\text { the ATM }\end{array}$ & $\begin{array}{l}\text { To start or combine } \\
\text { antibiotic }\end{array}$ & $\mathrm{N} / \mathrm{l}$ \\
\hline & & 7.2 & $\begin{array}{l}\text { Patient with no coverage for } \\
\text { Gram-negative bacteria and with } \\
\text { clinical or laboratory indication }\end{array}$ & $\begin{array}{l}\text { To start or combine } \\
\text { antibiotic }\end{array}$ & $\mathrm{N} / \mathrm{I}$ \\
\hline & & 7.3 & $\begin{array}{l}\text { Patient with no coverage for viruses } \\
\text { or fungi or parasite and with clinical } \\
\quad \text { or laboratory indication }\end{array}$ & $\begin{array}{l}\text { To start or combine } \\
\text { antiviral/ antifungal/ } \\
\text { antiparasitic }\end{array}$ & $\mathrm{N} / \mathrm{l}$ \\
\hline & & 7.4 & $\begin{array}{l}\text { Patient with no surgical } \\
\text { prophylactic ATM }\end{array}$ & $\begin{array}{l}\text { To start antibiotic } \\
\text { prophylaxis }\end{array}$ & $\mathrm{N} / \mathrm{l}$ \\
\hline & & 7.5 & $\begin{array}{l}\text { Patient with immunodeficiency or } \\
\text { other justified clinical condition } \\
\text { without prophylactic ATM }\end{array}$ & $\begin{array}{l}\text { To start antibiotic } \\
\text { prophylaxis }\end{array}$ & $\mathrm{N} / \mathrm{l}$ \\
\hline & & 7.6 & $\begin{array}{l}\text { Early suspension of ATM (without } \\
\text { clinical or microbiological cure) }\end{array}$ & Extend therapy & E \\
\hline & & 7.7 & $\begin{array}{l}\text { Patient without cover for } \\
\text { anaerobic bacteria and with } \\
\text { clinical or laboratory indication }\end{array}$ & Start or combine ATM & $N / I$ \\
\hline \multirow{5}{*}{8} & \multirow{5}{*}{ Dilution } & 8.1 & $\begin{array}{l}\text { Volume of the infusion solution } \\
\text { not prescribed (NS } 0.9 \% \text { or D5NS) }\end{array}$ & $\begin{array}{l}\text { To guide prescription of } \\
\text { ATM volume of dilution }\end{array}$ & $S$ \\
\hline & & 8.2 & Increased volume of dilution & $\begin{array}{l}\text { To decrease volume } \\
\text { of dilution }\end{array}$ & $S$ \\
\hline & & 8.3 & Decreased volume of dilution & $\begin{array}{l}\text { To increase volume } \\
\text { of dilution }\end{array}$ & $S$ \\
\hline & & 8.4 & $\begin{array}{l}\text { Dilution without stability for the } \\
\text { proposed infusion time }\end{array}$ & $\begin{array}{l}\text { To guide diluent } \\
\text { change }\end{array}$ & $\mathrm{E}$ \\
\hline & & 8.5 & $\begin{array}{l}\text { Inadequate diluent for the clinical } \\
\text { condition }\end{array}$ & To change diluent & S \\
\hline \multirow{3}{*}{9} & \multirow{3}{*}{ Infusion time/rate } & 9.1 & Extended infusion time & $\begin{array}{l}\text { To decrease infusion } \\
\text { time }\end{array}$ & E \\
\hline & & 9.2 & Decreased infusion time & $\begin{array}{l}\text { To increase infusion } \\
\text { time }\end{array}$ & $S$ \\
\hline & & 9.3 & $\begin{array}{l}\text { Absence of infusion time } \\
\text { prescription }\end{array}$ & $\begin{array}{l}\text { To prescribe infusion } \\
\text { time }\end{array}$ & $S$ \\
\hline 10 & $\begin{array}{l}\text { Therapeutic } \\
\text { ineffectiveness }\end{array}$ & 10.1 & $\begin{array}{l}\text { Use of ATM without effect in a } \\
\text { patient with confirmatory } \\
\text { examinations of infection to which } \\
\text { the microorganism is susceptible }\end{array}$ & To replace ATM & $N / I$ \\
\hline \multirow[t]{2}{*}{11} & \multirow{2}{*}{$\begin{array}{l}\text { Interaction drug-drug or } \\
\text { drug-food interaction }\end{array}$} & 11.1 & $\begin{array}{l}\text { Risk of decreased ATM } \\
\text { effectiveness }\end{array}$ & $\begin{array}{c}\text { To change the } \\
\text { schedule or replace } \\
\text { ATM }\end{array}$ & E \\
\hline & & 11.2 & $\begin{array}{l}\text { Increased risk of ATM reaction or } \\
\text { toxicity }\end{array}$ & $\begin{array}{l}\text { To change the schedule } \\
\text { or replace ATM }\end{array}$ & S \\
\hline \multirow{2}{*}{12} & \multirow{2}{*}{$\begin{array}{l}\text { Physical-chemical } \\
\text { incompatibility }\end{array}$} & 12.1 & $\begin{array}{l}\text { ATM incompatible with diluent or } \\
\text { medication }\end{array}$ & $\begin{array}{l}\text { To change schedule or } \\
\text { diluent or access route }\end{array}$ & E \\
\hline & & 12.2 & $\begin{array}{l}\text { Insufficient venous access } \\
\text { number for pharmacotherapy }\end{array}$ & $\begin{array}{l}\text { To change venous } \\
\text { access }\end{array}$ & $\mathrm{E}$ \\
\hline \multirow{4}{*}{13} & \multirow{4}{*}{ Drug administration } & 13.1 & $\begin{array}{l}\text { Patient does not receive ATM due } \\
\text { to prescription or administration } \\
\text { problems }\end{array}$ & $\begin{array}{l}\text { To request ATM } \\
\text { prescription or to } \\
\text { request ATM dose }\end{array}$ & $\mathrm{E}$ \\
\hline & & 13.2 & $\begin{array}{l}\text { Loss of stability due to delay in } \\
\text { ATM administration }\end{array}$ & $\begin{array}{l}\text { To change ATM and } \\
\text { guide the team }\end{array}$ & $\mathrm{E}$ \\
\hline & & 13.3 & $\begin{array}{l}\text { Delay in administration time } \\
\text { according to protocol }\end{array}$ & $\begin{array}{l}\text { To investigate the } \\
\text { cause and report }\end{array}$ & $\mathrm{E}$ \\
\hline & & 13.4 & $\begin{array}{l}\text { Inadequate scheduling of } \\
\text { dialysable medication }\end{array}$ & $\begin{array}{l}\text { To investigate the } \\
\text { cause and report }\end{array}$ & E \\
\hline \multirow{5}{*}{14} & \multirow{5}{*}{$\begin{array}{l}\text { Laboratory or imaging } \\
\text { tests to monitor the } \\
\text { therapeutic response }\end{array}$} & 14.1 & $\begin{array}{l}\text { Lack of renal and/or liver or other } \\
\text { system functions follow-up }\end{array}$ & $\begin{array}{l}\text { To request } \\
\text { examination }\end{array}$ & S \\
\hline & & 14.2 & $\begin{array}{l}\text { Absence/need for hemogram, } \\
\text { hemoculture and/or cultures }\end{array}$ & $\begin{array}{l}\text { To request } \\
\text { examination }\end{array}$ & Sor $\mathrm{E}$ \\
\hline & & 14.3 & Lack of ATM serum level & $\begin{array}{l}\text { To request examination } \\
\text { (serum dosage) }\end{array}$ & Sor $\mathrm{E}$ \\
\hline & & 14.4 & Absence of rapid diagnostic tests & $\begin{array}{l}\text { To discuss the request } \\
\text { for the examination } \\
\text { with the doctor }\end{array}$ & $S$ \\
\hline & & 14.5 & $\begin{array}{l}\text { Absence of imaging tests and } \\
\text { graphic methods }\end{array}$ & $\begin{array}{l}\text { To discuss the request } \\
\text { for the examination } \\
\text { with the doctor }\end{array}$ & S or E \\
\hline
\end{tabular}




\begin{tabular}{|c|c|c|c|c|c|}
\hline Code & $\begin{array}{c}\text { Primary domain of the } \\
\text { problem identified }\end{array}$ & Subcode & PRAT Description & $\begin{array}{c}\text { Suggested } \\
\text { intervention }\end{array}$ & $\begin{array}{c}\text { Classification of the } \\
\text { problem }\end{array}$ \\
\hline \multirow{4}{*}{15} & \multirow{4}{*}{ Device } & 15.1 & $\begin{array}{l}\text { Infected catheter without } \\
\text { possibility of lock therapy }\end{array}$ & $\begin{array}{l}\text { To consider catheter } \\
\text { removal }\end{array}$ & $S$ \\
\hline & & 15.2 & $\begin{array}{l}\text { Infected catheter with possibility } \\
\text { of lock therapy }\end{array}$ & $\begin{array}{l}\text { To start lock therapy } \\
\text { according to the } \\
\text { protocol }\end{array}$ & $N / l$ \\
\hline & & 15.3 & $\begin{array}{l}\text { Absence of prophylaxis in } \\
\text { patients with long-term catheter } \\
\text { according to the protocol }\end{array}$ & To start taurolidine & $N / I$ \\
\hline & & 15.4 & Device obstruction & $\begin{array}{l}\text { To remove device or } \\
\text { clearance measures }\end{array}$ & $N / I$ \\
\hline \multirow{3}{*}{16} & \multirow{3}{*}{ Doctor's prescription } & 16.1 & Typing error (dose, unit, route) & $\begin{array}{l}\text { To correct dose } \\
\text { prescription }\end{array}$ & S or E \\
\hline & & 16.2 & ATM prescription duplication & $\begin{array}{l}\text { To suspend one of } \\
\text { the prescribed ATMs }\end{array}$ & $\mathrm{S}$ \\
\hline & & 16.3 & $\begin{array}{l}\text { Absence of dose prescription or } \\
\text { medical prescription }\end{array}$ & To prescribe dose & $E$ \\
\hline \multirow{3}{*}{17} & \multirow{3}{*}{ Adverse reaction } & 17.1 & $\begin{array}{c}\text { Risk of adverse reaction to ATM } \\
\text { (eg: leakage, allergy, kidney } \\
\text { damage) }\end{array}$ & $\begin{array}{l}\text { To start } \\
\text { premedication } \\
\text { and/or hydration }\end{array}$ & $\mathrm{S}$ \\
\hline & & 17.2 & $\begin{array}{c}\text { Reaction with oral ATB predicted } \\
\text { or not in package insert and } \\
\text { clinically significant }\end{array}$ & $\begin{array}{l}\text { To transition ATM } \\
\text { oral to IV or replace } \\
\text { ATM }\end{array}$ & $\mathrm{S}$ \\
\hline & & 17.3 & $\begin{array}{c}\text { Reaction with oral ATM predicted } \\
\text { or not in package insert and } \\
\text { clinically significant }\end{array}$ & $\begin{array}{l}\text { To suspend or } \\
\text { replace ATM IV }\end{array}$ & $\mathrm{S}$ \\
\hline
\end{tabular}

Note: ATM, antimicrobial; IV, intravenous; N/A, not applicable; PRAT, antimicrobial therapy related problem. * Impact refers to a didactic classification to attribute whether the pharmacotherapeutic intervention was related to the ATM use (or not) necessity/indication (N/I), the ATM effectiveness (E) or the ATM safety (S), which means, whether the PRAT caused or could cause an adverse event to the patient.

This tool has 17 categories and 67 subcategories as demonstrated in Table 1 . The categories are called the primary domain of the identified problem and are as follows: prescribed dose; frequency, route of administration; dose form, unnecessary or inappropriate medication; inadequate pharmacotherapy; insufficient pharmacotherapy; dilution, infusion time/rate; therapeutic ineffectiveness; interaction drug-drug or drug-food interaction; physical-chemical incompatibility; drug administration; laboratory or imaging tests to monitor the therapeutic response or toxicity; device, doctor's prescription (items related to the process); and adverse reaction.

The 67 subcategories are the description of the PRAT, that is, they are all the specific and possible problems encountered with antimicrobials described in detail. These subcategories can have the consequence of not reaching the desired therapeutic objective (compromising effectiveness) or the appearance of undesirable effects (compromising safety) or even unnecessary or not indicated use (need / indication).

In order to characterize the problems addressed in the tool, in the PRAT table it chassification of the problems is suggested, allowing the interventions to be prioritized in a future step. The problem can compromise the following aspects:

- Effectiveness: problems that will affect the therapeutic effect of the treatment, such as underdose (subcode 1.1, 1.2 or 1.3)

- Safety: refers to the potential for adverse reaction or toxicity, such as overdose interventions (subcode 1.4, 1.5 or 1.6)

- Need/indication: this relates to whether the patient needs the antimicrobial or not or whether or not the use is indicated, according to clinical and laboratory parameters, such as, for example, prolonged antibiotic therapy time (subcode 5.2) or a patient without coverage to determine the microorganism (subcodes 71, 7.2 and 7.3).

In addition, the PRAT table also presents the respective proposals for pharmacotherapeutic interventions that are recommended for each specific problem. These proposed interventions 
(related to 17 domains and 67 subcategories) are according to identified PRAT and areperformed to improve the patient's clinical results.

A key point in the design, evaluation and implementation of the proposed pharmacotherapeutic intervention is the acceptability by the healthcare team (mainly medical and nursing staff). Thus, it is essential that, based on the identification of the PRAT and its respective intervention, the degree of acceptability of this conduct (intervention) carried out by the ASP team is measured, being classified as "accepted", "not accepted with justification" and "not accepted without justification".

Furthermore, this classification system has some considerations and follow these examples:

I. Pharmacotherapeutic counseling is not addressed by our tool, because it is different from pharmacotherapeutic intervention. The intervention is a recommendation initiated in response to a drug-related problem in an individual patient at any stage of the medication process, whilst the counseling is performed prior to the occurrence of PRAT, in order to prevent this problem.

II. Intervention is not a group of activities, however the professional acts to improve the use of antimicrobial agents or infectious diseases diagnosis and monitoring for every single patient.

III. Different from that previously suggested by other authors ${ }^{11}$, from our PRAT system perspective, an intervention is not a formulary restriction, but is a specific and punctual action during the process of using the antimicrobial, such as the suggestion to interrupt or replace the antimicrobial due to the wrong choice of the same for a specific infection in a patient. Therefore, the ASP intervention is unique for each patient.

IV. In addition, the identification of the intervention alone is not sufficient. Our tool is more specific in describing the problem than in the format described by other authors, who focus on reporting interventions without presenting their causes. For example, the PRAT system promotes that the antimicrobial de-escalation is a reduction in the antimicrobial therapy spectrum, in which the problem is the choice of an empirically expanded spectrum therapy, after the identification of the antimicrobial-resistance profile (subcode 6.9).

V. The acceptability of interventions is an important aspect to consider in the phases of development, evaluation and implementation of pharmacotherapeutic interventions. Successful implementation depends on the acceptance rate by the care team. If an intervention is considered logical and based on clinical, technical and scientific precepts and, therefore, acceptable, it will be more likely to adhere to treatment recommendations and benefit from the best clinical results. In addition, acceptability helps the ASP team to make decisions about the form, content and delivery of the proposed intervention components.

As this is the first tool attempting to unify the interventions performed by ASP, many positive aspects would be enhanced, as described below:

I. ASP reports usually focus on "inappropriate dose"12. Such information is a reduced way of sharing knowledge. ASP professionals want to know the underlying situation that resulted in an incorrect dose and the intervention for it. For example: reduced renal clearance (the problem) and reduction in the dose of antibiotics with elimination mainly at the renal level (the intervention) is a more informative process that might increase critical thinking and local decision-making (subcode 1.6). Using this tool, the impact of ASP interventions on relevant outcomes will be less heterogeneous, so it will contribute with appropriate group comparisons.

II. The use of this classification system optimizes the evaluation of pharmacotherapeutic interventions and the acquisition of antimicrobial-related problem in a structured way, favoring the continuity of care through the promotion of mutual information. Moreover, this data can be used for epidemiological data and increases the ASP' vigilance regarding patient needs related to medications. 
The tool is not without limitations:

I. Despite our experience of its use, the PRAT was not validated. We strongly believe that making this publicly available will promote discussions and development about harmonizing ASP interventions.

II. Not all PRAT presented by this tool might be considered by different ASPs, so each institution should adapt and make the best use of this tool to register the problems and interventions.

III. Understanding the description of the PRAT is not simple, requiring some time for the incorporation and appropriation of this new practice. A suggestion to reduce this limitation is to implement local software and electronic medical records in order to create epidemiological data

A single antimicrobial-related problem system will promote less heterogeneous reports, benchmarking and innovation, as ASP practitioners will understand what interventions should be prioritized and to what extent they affect clinical and economic outcomes. Through this tool, the economic impact of the pharmacotherapeutic intervention can be measured in the near future.

\section{ACKNOWLEDGMENTS}

The authors express their gratitude for research funding to the Pequeno Principe Children's Hospital for support of Stewardship Program Interventions

\section{REFERENCES}

1. Dyar OJ, Huttner B, Schouten J, Pulcini C. What is antimicrobial stewardship? Clin Microbiol Infect. 2017;23(11):793-8. http://dx.doi.org/10.1016/j.cmi.2017.08.026.

2. Garau J, Bassetti M. Role of pharmacists in antimicrobial stewardship programmes. Int J Clin Pharm. 2018;40(5):948-52. http://dx.doi.org/10.1007/s11096-018-0675-z. PMid:30242589.

3. Rice LB. Antimicrobial stewardship and antimicrobial resistance. Med Clin North Am. 2018;102(5):805-18. http://dx.doi.org/10.1016/j.mcna.2018.04.004. PMid:30126572.

4. Cambridge Dictionary. [Internet]. Cambridge: Cambridge University Press; 2020 [cited 2020 Feb 26]. Available from: https://dictionary.cambridge.org/pt/dicionario/ingles/promote

5. CLSI. [Internet]. USA: Clinical and Laboratory Standards Institute; 2020 [cited 2020 Feb 26]. Available from: https://clsi.org/about/clsis-history/

6. Bassetti M, Poulakou G, Ruppe E, Bouza E, Van Hal SJ, Brink A. Antimicrobial resistance in the next 30 years, humankind, bugs and drugs: a visionary approach. Intensive Care Med. 2017;43(10):146475. http://dx.doi.org/10.1007/s00134-017-4878-x. PMid:28733718.

7. Gentry EM, Kester S, Fischer K, Davidson LE, Passaretti CL. Bugs and drugs: collaboration between infection prevention and antibiotic stewardship. Infect Dis Clin North Am. 2020;34(1):17-30. http://dx.doi.org/10.1016/j.idc.2019.10.001. PMid:31836329.

8. Schuts EC, et al. Current evidence on hospital antimicrobial stewardship objectives: a systematic review and meta-analysis. Lancet Infect Dis. 2016;16(7):847-56. http://dx.doi.org/10.1016/S14733099(16)00065-7. PMid:26947617.

9. Van Dijck C, Vlieghe E, Cox JA. Antibiotic stewardship interventions in hospitals in low-and middleincome countries: a systematic review. Bull World Health Organ. 2018;96(4):266-80. http://dx.doi.org/10.2471/BLT.17.203448. PMid:29695883.

10. Basger BJ, Moles RJ, Chen TF. Application of drug-related problem (DRP) classification systems: a review of the literature. Eur J Clin Pharmacol. 2014;70(7):799-815. http://dx.doi.org/10.1007/s00228014-1686-x. PMid:24789053.

11. Hou D, Wang Q, Jiang C, Tian C, Li H, Ji B. Evaluation of the short-term effects of antimicrobial stewardship in the intensive care unit at a tertiary hospital in China. PLoS One. 2014;9(7):e101447. http://dx.doi.org/10.1371/journal.pone.0101447. PMid:25000225. 
12. Song $P$, Li W, Zhou Q. An outpatient antibacterial stewardship intervention during the journey to $\mathrm{JCl}$ accreditation. BMC Pharmacol Toxicol. 2014;15(1):8. http://dx.doi.org/10.1186/2050-6511-15-8. PMid:24568120.

\section{Authors' contributions}

All authors of this manuscript participated directly in the planning, execution and writing of this study, in which each author had the following contribution: MR contributed to conceptualization, project administration, methodology, data curation, visualization, supervision and writing - review and editing; LO contributed to conceptualization, visualization, methodology, writing original draft and writing review e editing; HB contributed to conceptualization, project administration, methodology, data curation, visualization and supervision; HPN contributed to conceptualization, methodology, visualization and writing review e editing; DS contributed to conceptualization, methodology and visualization; MF contributed to methodology, writing original draft and writing review e editing; FM contributed to conceptualization, project administration, supervision, validation, data curation, and writing - review and editing. 